\title{
Ho Chi Minh's Human Love
}

\author{
Master. Nguyen Thi Khuyen \\ Political Theory Department, Tay Nguyen University
}

\begin{abstract}
Ho Chi Minh was a Cultural, Great leader of the Vietnam revolution, a hero of Vietnam national liberation. Ho Chi Minh was a person who special interested in morality throughout the life of revolutionary activities. Moreover, Ho Chi Minh was also a person who thoroughly practices his moral sentiments. In which, covering all was the great love of Ho Chi Minh to the people of all circles, all sectors, all classes, which built from childhood and intact until Ho Chi Minh vented his last breath. That noble sentiment inspired Ho Chi Minh to embark on a revolutionary career with the sacrifice of hardship to get the mastery, a freedom, and happiness for the people. That sentiment was expressed naturally in Ho Chi Minh, from worries for big things like liberating people, building human development strategies to simple things associated with every human being with accomplishments specific scene. In this article, the author clarifies the love of people of Ho Chi Minh expressed through the years of revolutionary activities and by the sacred will of Ho Chi Minh left before going into eternity.
\end{abstract} Keywords: Vietnam revolution, Ho Chi Minh

DOI: $10.7176 /$ RHSS/9-6-03

Publication date:March $31^{\text {st }} 2019$

\section{The Beginning}

It was rarely to have the leader in the world like Ho Chi Minh, from the beginning of his revolutionary career to the last days of his life, from when he was a proletarian of a slave country to he was at the top of power, when he was the head of the Party and State which was an independent country, he only knew to Fatherland, the people, there were nothing for himself, was pure and upright. Love to human, love to people was the shining torch for Ho Chi Minh to have a journey - a life, a revolutionary career tirelessly for people, for the people. When preparing to leave this world, in the Will, Ho Chi Minh affirmed that there was nothing to regret, only regret that he could no longer serve the Fatherland and the people much longer, more. That deep Will was also be filled with Ho Chi Minh's love, the attention and concern for everyone. The life of Ho Chi Minh was a spotless example of the complete sacrifice for the high ambition and ideal for people, first of all for the people of Vietnam.

\section{History of subject research}

There have been many domestic and foreign scientists studying Ho Chi Minh's morality in general and Ho Chi Minh's human love in particular. Here are the most outstanding works that the author has inherited and developed in his article.

- Ho President, the essence of Nation, conscience of the age of Pham Van Dong. As one of the closest students, the author described Ho Chi Minh's portrait as an extremely simple, polite and elegant person. In Ho Chi Minh, it is the harmony between the simple material life and the rich life of the soul, with beautiful ideas, feelings and high spiritual values. The author generalized Ho President's life as an austere, hard-working life and struggled to seek happiness for the tomorrow of the nation and the people. The victory of the Vietnamese revolution is led by genius, the ability to unite the whole Vietnamese nation of Ho Chi Minh. That solidarity is achieved by the President's heart as wide as the sea, tolerant, sensitive, loving all people, guiding people.

- The book named "Ho Chi Minh star shining in the sky of Vietnam" by Vu Khieu. This is a big monograph, gather the research results for many years by Vu Khieu. Part II of the book "Ho Chi Minh with moralities subject" is special attested by the author which clarified very profound content. The author has made a exactly consider: "Ho Chi Minh's idea of morality is the most important part of Ho Chi Minh's whole ideological system" and has made compelling arguments. Not only did the important characteristics of morality for the Vietnamese revolution as well as the new moral standpoint, Ho Chi Minh was the full moral example of the commitment to the country, the filial piety of the people; love people, live love, mean; lifelong patiently studying and practicing new morality, ... Ho Chi Minh is a great example of the ethics of the Vietnamese people.

- The Book named "Ho Chi Minh - a great person" of Tran Van Giau. The author has systematically presented the legendary life of President Ho Chi Minh. The author analyzed out seven points out of qualities, seven characteristics in Ho Chi Minh's personality, in which outstanding qualities are: devotion to selflessness; modest, simple; love, precious people; support people. These are important factors that make Ho Chi Minh greatness. Ho Chi Minh devoted his all life to the revolutionary cause of the Vietnamese people, who had no other desires in all his life other than the ultimate desire to make the country completely independent and human are completely free, everyone has food, clothes, everyone can study. 
- "The morality of Ho Chi Minh is a shining example for ever" by Tran Viet Hoan, who directly protected Ho Chi Minh in the last years of his life. With a short, rustic writing, the author recreates the life of revolutionary activities as well as daily life activities of Ho Chi Minh in an honest, clear, vivid and closer way than ever before. According to the author, Ho Chi Minh - the people for a great gratitude to the nation. All his enthusiasm and life are associated with the destiny of the nation, the identity of every people. From the observation and contemplation of Ho Chi Minh's moral example, the author has drawn a profound lesson in Ho Chi Minh that each of us needs and can study and train under, that is: loyalty Fatherland, with people; love people; for people to respect and set an example, to live modestly, simply, economically; taking coupled to doing,...

- Summary record of the conference "Will of President Ho Chi Minh - Values of history and age" organized by National University of Ho Chi Minh city. The conference was an opportunity to look back all the done work in forty years of Ho Chi Minh's Will processing, review the nation's journey, use it as the luggage for the next way to go, continue to carry on full doing of Ho Chi Minh's will is to build a peaceful, united, independent, democratic and rich Vietnam, contributing to protecting world peace. In which, in the fifth theme "Lots of love", the articles clarified the beautiful moral sentiments of Ho Chi Minh. It is the love which sent by Ho Chi Minh in the Will to the nation, the war invalids, martyrs, women and especially the youth, children and youth child.

\section{Contents}

\subsection{The Human Love of Ho Chi Minh in the revolutionary activities years}

Firstly, Human love of Ho Chi Minh derived from the human nature of traditional Vietnamese morality. This was clearly reflected in the community psychology and behavioral requirements of all members. This love is not the giving, the pity but the inclusion of "Loving people as love ourselves". This love also comes from the meaning of "nation", same ancestors and roots through the legend of children of the Fairy and the Dragon, therefore, becoming more and more strong and sacred

\section{"Bau oi thuong lay bi cung}

Tuy rang khac giong nhung chung một gian.

From the beginning, because of human love, first of all is "fellow nation and depressed" was the driving force to urge Ho Chi Minh to seek a way to liberate the nation, bringing freedom to the people. That way with endless dangers awaits Ho Chi Minh: many times being convict to death, experiencing by thirty prisons, living with a lot of hard work in many different countries (discussing, washing photos, Snow removal, gardening, ...). For Ho Chi Minh, all difficulties were the environment to train to achieve his goals.

"Gao dem gia bao dau don

Gao gia xong roi trang tua nhu bong

Song o tren doi nguoi cung vay

Gian nan ren luyen moi thanh cong" [11, page no.164].

Purpose of whole Ho Chi Minh life was only Independence Country, Happiness Nation "My whole life has only one purpose, it is striving for national welfare, and happiness nation. When I have to hide in the mountains, or go to prisons, to make a danger - for that purpose ... Anytime, anywhere, I just pursue a purpose, make national benefit and nation benefit "[7, page no. 272]. The ideal of living voluntarily sacrificing for the nation, the source of sustaining the will and extraordinary energy because of nation, let Ho Chi Minh to overcome difficulties and challenges. We see the encounter in the ideal of the great people as Ho Chi Minh and C. Marx, in the minds of young people when choosing a career, C. Marx wrote: "If we choose a career in which we can work more for humanity, then we will not be hunched under its burden, because it is a sacrifice for everyone "[5, page no.110]. Receiving Marxism-Leninism, that beautiful sentiment in Ho Chi Minh is not only limited to people-topeople correlation, national correlation but also extends into the correlation of oppressed people. Ho Chi Minh wrote: "So, even though the skin color is different, there are only two types of human beings in this world: like the exploiters and the exploited ones. But only one love affair is true: proletariat love [6, page no.287]. MarxismLeninism has affirmed that man is the subject of history, the driving force of revolution. Therefore, people are not only pitiful, accepting the sympathy of others but can also unite together to free themselves. Loving the people, believing in them, Ho Chi Minh educated and united them into a great force to destroy all the shackles of the colonialists, empires and build a new life with prosperity and happiness.

After gaining national independence by the fighting, Ho Chi Minh always wondered how to get people to enjoy freedom, happiness, because the country was independent and the people could not enjoy freedom and happiness, That makes no sense. According to Ho Chi Minh, it is also a fight, a huge fight takes in all areas of social life in which the people are not only the root, the foundation but also the people is owner. It means, how many benefits are for the people; how many powers are of the people. Fighting, building the country is right of people. Government from the commune to the central government elected by the people. Authority and force are in the people. People not only elect but they also have control and disregard for governments at all levels. Officials from the Central to the commune must be a true loyal servant of the people. The work of the Government must be aimed at a single purpose of plotting freedom and happiness for all. So the people's 
government always has to put people's interests above all. What works for the people is good. What is harmful to the people must be avoided" [7, page no. 21]. Ho Chi Minh himself also considered the President of the country entrusted by the people, so he tried to do, as well as a soldier obeying the national order to the front. Many times reminded by Ho Chi Minh, officials of State must rely on people, closely contact with people, listen to people's opinions. To do something must have the masses, based on the masses, without the masses, it cannot be done: "It is easy for ten times to not bear if without the people, and hundreds of times are finished if have the people" [10, page no. 280]. "The original has a strong new tree, built a floor to win on the people's foundation" [8, page no. 502]. "In the sky nothing is as precious as the people. In the world, nothing is as strong as the unity of the people "[9, page no. 453]. Democracy in Ho Chi Minh is not a dry theory but it is full of life, it transforms Vietnamese and Vietnamese people. Democracy has turned every Vietnamese person into an enlightened, intelligent, and talented person to own a country.

Not only is concerned about the problems of the people as a great leader and leader of the country, Ho Chi Minh also devoted his honest love, caring as a grandfather and father in the family. No one in the Vietnamese family has no place in Ho Chi Minh's heart. The touching stories tell about the actions and gestures that seem small and simple but Ho Chi Minh's heart to the people is immense. Love tenderly the workers who sweep the streets at late nights in winter, Ho Chi Minh reminded their person in charge to allocate work clothes to protect their health. When traveling abroad, Ho Chi Minh also bought some winter trees which less deciduous trees so that the workers could save their labor to sweep the road. Another story recounted, in the summer of Hanoi capital in 1967, love tenderly the air defense soldiers on the roof of Ba Dinh Hall in the hot sky, Ho Chi Minh transferred all the savings which were obtained by the newspapers royalties to buy soft drinks for them ... Between pretty crowed with the work of country and housework but Ho Chi Minh always understands and seeks to share the suffering of the people. Because of the love of poor people and the misery of being President, Ho Chi Minh still kept the frugality, hard-working, and suffering from meals, stationary, houses to the way of life. The meal has only a few simple dishes. The appreciation of human production results and respect for the waiters, so while eating, Ho Chi Minh did not drop a grain of rice, finished eating, the bowl was always clean and the remaining food was neatly arranged. . The simple floor house in Ho Chi Minh is only a few three rooms, always fully of windy, light and subtle with the scent of flowers in the garden. We feel from Ho Chi Minh, the simpler the material life, the richer the life of the soul, the more thoughts, feelings, spiritual values become. A-lan Abon (An Australian writer) talked about Ho Chi Minh: "He does not behave like a ruler, but in an important sense, he obtains the hearts and minds of the Vietnamese people. The difficulty of Westerners in trying to understand it, that in the West, presidents, prime ministers, kings and generals almost always prove and act like rulers, surrounding them. by the flowers and rituals, conveyed by gesture, a commanding attitude; Ho Chi Minh is a different leader "[12, page no. 124]. The highlight of Ho Chi Minh, which differently with Western politicians, is the consistency of the political life that shakes the earth with the simple, humble, ordinary life. That consistency is easy to understand because it is Ho Chi Minh, people have devoted their whole lives, giving their whole thoughts and feelings to the country and the people. A person who considers the sadness and worries of every Vietnamese person is his own. The last moments of Ho Chi Minh's life remained on the side of the revolutionary cause, still interested in the people of all strata. In the hospital bed in the last minute of death, Ho Chi Minh still spent his thoughts and worries on the people in the rainy season, breaking down dyke, asking if he could evacuate the people or not, and coming to the opening day, he took care of the school, Booklet for young children.

\subsection{Human love of Ho Chi Minh in the Will}

The will is the last priceless nerve property that Ho Chi Minh left for the nation and people of Vietnam. Regarding the reason for writing the Will, Ho Chi Minh expressed thoughtfulness, caring wholeheartedly toward the people, that is to prevent people from feeling abruptly when going into eternity. The Will was drafted by Ho Chi Minh in 1965, some years passed, on the occasion of May, Ho Chi Minh read it, fix it again and write more. Thus, Ho Chi Minh spent four years thinking about death, thoroughly worrying about his death. That worry is mainly about revolution, about Vietnamese people.

With simple words, Ho Chi Minh called "these words", but the Will contained a rich, profound content and filled with love left for everyone. For young people, the mainstay of the revolution, the force mainly building the future society. Ho Chi Minh is very reliable at young age. Ho Chi Minh instructed that the Party should take care of the revolutionary moral education for them, train them into the heirs to build socialism and "pink" and "specialize". Ho Chi Minh thesis expressing the enthusiasm. with the young generation "Fostering the revolutionary generation for the next life is a very important and necessary work". Ho Chi Minh plans after the victory day, choose some of the most elite, let them go to learn more business and professions to train them to be good offices technicians who have good thinkers, stand the way solid network. That will be the main force in the construction of victorious socialism in our country.

For women, Ho Chi Minh respects their worthy contributions and relies on them with their deep feelings. 
Ho Chi Minh special interested in women's development, progress, equality and happiness in life. Ho Chi Minh reminded the Party and the Government to have a practical plan to foster and remind and help more women take care of all tasks including leadership. Ho Chi Minh also encouraged women to try to rise. It is a revolution that leads to real equality for women.

With farmers, people who have made great contributions and sacrifices in historical periods, Ho Chi Minh also have the most interested in. Ho Chi Minh suggested that after being completely successful, it would exempt agricultural cooperatives one year tax for agricultural cooperatives to make their people happy, comfortable, more excited and boosted production.

Ho Chi Minh expressed a special interest in those with meritorious services to the country, with families of war invalids and martyrs. We have to take care of them carefully, take care of places to eat, shelter, work, life for them, absolutely do not let anyone fall into hunger, deprivation, must show gratitude to those who have contributed strength, wealth, even your life for revolutionary careers. Must do practical things to educate tradition, eternally grateful to heroes and martyrs.

For the victims in the old regime, Ho Chi Minh instructed to have the generous, to use policies, laws, and administration to help them become honest people, live in the solidarity and harmony of the ethical people regulations, human love.

For people working in lowland areas as well as in mountainous areas, Ho Chi Minh devoted deep love and sympathy. Their lives suffered hardship, were oppressed by the feudal regime and practically oppressed by the regime, and experienced many years of war. Therefore, according to Ho Chi Minh, it is necessary to have a good plan to develop the cultural economy, in order to constantly improve the lives of the people.

When saying "about personal affairs", it exudes the beautiful and noble soul of Ho Chi Minh, sacrificing, forgetting everything that belongs to him, to think about the people. Ho Chi Minh sincerely instructed: "When I passed away, do not organize a lump of spirit, so as not to waste people's time and money" [10, page no. 623]. Ho Chi Minh devoted his entire life to the nation, even bone ash offered to give to the compatriots. "The ash is divided into three parts, put into three gourmet boxes. One box for the North. A box for Central. One box for the South "[10, page no.615]. With Ho Chi Minh, nothing belongs to the private, the heart, the mind, the life, the career and finally the ashes, Ho Chi Minh also gives all to the people and the people.

\section{The End}

Ho Chi Minh is a thinker of revolutionary action. Perhaps, Ho Chi Minh "reluctantly" became a thinker. That also does not reduce the size of Ho Chi Minh - a sage. The Greatness in Ho Chi Minh does not stop at ideological contributions, but above all, in Ho Chi Minh's life full of commitment and arduous struggle for national independence, freedom and happiness. happiness of fellow citizens. We fully agree with GS's position. Tran Van Giau wrote: "Allow me to understand that the size of a sage is not certain in answering the relationship between existence and thought, in determining the world as reality or illusion, which is possible tri or agnostic, in choosing the familiar or creative doctrine, which, in general, is concerned with the person, the real person living on this earth and will probably live forever time, take it as the center of all thoughts, be the purpose of all actions. Uncle Ho belonged to this kind of sage "[3, page no. 289]. Great thought and moral example of Ho Chi Minh was able to spread strongly not only in the twentieth century, not only to the people of Vietnam but also to humanity.

\section{REFERENCES}

1. Ho Chi Minh National University (2010), Summary record of the conference "Will of President Ho Chi Minh Values of history and age", National University of Ho Chi Minh City Pulishing House.

2. Pham Van Dong (1975), Ho President, the essence of the nation, conscience of the age, The Truth Publishing house.

3. Tran Van Giau (2010), Ho Chi Minh - a great person, National politics Publishing house.

4. Tran Viet Hoan (2017), Uncle Ho's morality example for ever, National politics truth Publishing house.

5. ÊLêna ILiina (1966), Youth of Marxists, Publishing House. Youth.

6. Ho Chi Minh (2011), Complete Edition, Episode 1, National politics, Hanoi Publishing House.

7. Ho Chi Minh (2011), Complete Edition, Episode 4, National politics, Hanoi., Publishing House

8. Ho Chi Minh (2011), Complete Edition, episode 5, National politics, Hanoi Publishing House.

9. Ho Chi Minh (2011), Complete Edition, Episode 10, National politics, Hanoi Publishing House.

10. Ho Chi Minh (2011), Complete Edition, Episode 15, National politics, Hanoi Publishing House.

11. Ho Chi Minh (1983), Diary in prison, Literature, Hanoi Publishing House.

12. Many authors (1990), International Conference on President Ho Chi Minh, Social science Publishing House. 